EDITORIAL

\title{
Revista Ciência da Informação 100\% eletrônica
}

Adaptada às mudanças e com características inovadoras requeridas pela sociedade da informação, a revista Ciência da Informação - cuja trajetória compreende o período de 1972 a 1995, edição impressa, e 1996 a 2003, edição impressa e on-line - lança, em 2004, sua edição totalmente eletrônica, ganhando nova alma.

A tendência mundial nos aponta para a disponibilização de conteúdos digitais por meio de ferramentas de acesso aberto. A adesão a essas tecnologias proporciona simultaneamente a sistematização dos processos editoriais, resultando em maior agilidade na edição da publicação, assim como na diminuição dos custos de impressão, solução para um contexto restritivo de recursos orçamentários.

Ao lançar o volume 33 , número 1 de 2004, a revista completa em sua totalidade o $72^{\circ}$ fascículo, atingindo um novo marco. Com isso, o Ibict, ao completar 50 anos de fundação (1954-2004) trabalhando com o tratamento, organização, disponibilidade, disseminação e acesso democratizado de conteúdos de informação e conhecimento em ciência e tecnologia no País, sente-se duplamente honrado.

A partir deste fascículo, o Ibict coloca à disposição da comunidade a revista automatizada pelo novo Sistema Eletrônico de Editoração de Revistas (SEER).

A revista passa a oferecer uma ferramenta interna de busca aos artigos e a disponibilizá-los para acesso mundial via internet. Os autores farão a submissão dos trabalhos diretamente no sistema e poderão acompanhar todo o processo de publicação dos artigos submetidos.

O SEER é uma adaptação, desenvolvida pelo Ibict, do software livre Open Journal System, criado pela University of British Columbia, seguindo a filosofia dos Open Archives. Trata-se de um pacote de software a ser repassado à comunidade de editores de publicações eletrônicas, por meio de download, brevemente disponível no site do Ibict. Além disso, serão promovidos workshops para o treinamento na utilização e transferência da nova tecnologia, o que contribuirá certamente para a melhoria do padrão editorial de publicações nacionais.

\section{Paulo Blanco Barroso \\ Diretor do Ibict}

